\title{
Effect of diurnal temperature range on emergency room visits for acute upper respiratory tract infections
}

\author{
Jin Young Jang ${ }^{1}$ and Byung Chul Chun ${ }^{1,2^{*}}$ (D)
}

\begin{abstract}
Background: An acute upper respiratory tract infection (URI) is the most common disease worldwide, irrespective of age or sex. This study aimed to evaluate the short-term effect of diurnal temperature range (DTR) on emergency room (ER) visits for URI in Seoul, Korea, between 2009 and 2013.

Methods: Daily ER visits for URI were selected from the National Emergency Department Information System, which is a nationwide daily reporting system for ER visits in Korea. URI cases were defined according to International Classification of Diseases, $10^{\text {th }}$ Revision codes J00-J06. The search for DTR effects associated with URI was performed using a semi-parametric generalized additive model approach with log link.

Results: There were 529,527 ER visits for URI during the study period, with a daily mean of 290 visits (range, 741942 visits). The mean daily DTR was $8.05^{\circ} \mathrm{C}$ (range, $1.1-17.6^{\circ} \mathrm{C}$ ). The cumulative day (lag 02) effect of DTR above $6.57^{\circ} \mathrm{C}$ per $1{ }^{\circ} \mathrm{C}$ increment was associated with a $1.42 \%$ (95\% confidence interval [Cl] 0.04-2.82) increase in total URI. Children ( $\leq 5$ years of age) were affected by DTR above $6.57^{\circ} \mathrm{C}$ per $1{ }^{\circ} \mathrm{C}$, with $1.45 \%(95 \% \mathrm{Cl} 0.32-2.60)$ at lag 02 , adults (19-64 years) with $2.77 \%(95 \% \mathrm{Cl} 0.39-5.20)$ at lag 07 . When the DTR (lag02) was $6.57^{\circ} \mathrm{C}$ to $11.03{ }^{\circ} \mathrm{C}$, the relative risk was significant at $6.01 \%(95 \% \mathrm{Cl} 2.45-9.69)$ for every $1{ }^{\circ} \mathrm{C}$ increase in youth subjects aged for 6 to 18 years.
\end{abstract}

Conclusions: DTR was associated with a higher risk for ER visits for URI. In addition, the results suggested that the lag effects and relative risks of DTR on URI were quite different according to age.

Keywords: Acute upper respiratory tract infections, Diurnal temperature range, Time-series, Climate factors

\section{Introduction}

Acute upper respiratory tract infections (URI), which include nasopharyngitis (common cold), sinusitis, pharyngitis, tonsillitis, tracheitis, and epiglottitis, are the most common diseases worldwide, irrespective of age or sex [1]. URI are caused by a wide variety of viruses and bacteria [2]. The incidence of the common cold ranges from 6 to 10 episodes per year in preschool-age children, 7 to 12 in

\footnotetext{
* Correspondence: chun@korea.ac.kr

'Department of Public Health, Korea University Graduate School, Seoul, Republic of Korea

${ }^{2}$ Department of Preventive Medicine, Korea University College of Medicine, Seoul, Republic of Korea
}

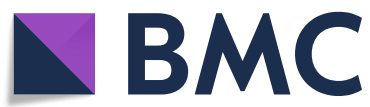

(c) The Author(s). 2021 Open Access This article is licensed under a Creative Commons Attribution 4.0 International License, which permits use, sharing, adaptation, distribution and reproduction in any medium or format, as long as you give appropriate credit to the original author(s) and the source, provide a link to the Creative Commons licence, and indicate if changes were made. The images or other third party material in this article are included in the article's Creative Commons licence, unless indicated otherwise in a credit line to the material. If material is not included in the article's Creative Commons licence and your intended use is not permitted by statutory regulation or exceeds the permitted use, you will need to obtain permission directly from the copyright holder. To view a copy of this licence, visit http://creativecommons.org/licenses/by/4.0/ The Creative Commons Public Domain Dedication waiver (http://creativecommons.org/publicdomain/zero/1.0/) applies to the data made available in this article, unless otherwise stated in a credit line to the data.

children in elementary school and, in adolescents and adults, from two to four episodes [2, 3]. Symptoms of URI commonly include cough, nasal congestion, and discharge, facial pain, sneezing, fever, headache, myalgia, and malaise [4]. These symptoms usually resolve after approximately 1 week. However, URI sometimes predispose to complications such as pneumonia and are the leading cause of economic burden on healthcare resources, as well as absences from work and/or school [3].

Seasonal variation in the incidence of URI is a common phenomenon, there is a widely held folklore that rapid changes in air temperatures are the cause of URI 
epidemics [5]. Diurnal temperature range (DTR) generally is defined as the difference between maximum and minimum temperatures within a single day. In previous studies, a $1{ }^{\circ} \mathrm{C}$ decrease in temperature increased the estimated risk for URI incidence [6,7]. The occurrence of URI increases in response to every $1{ }^{\circ} \mathrm{C}$ increase in DTR [8-10]. In addition, recent studies in Korea proposed that respiratory diseases are affected by increases in DTR [11-13]. There is also a study that analyzed the years of life lost (YLL) among health effects related to DTR [14]. As far as we know, no previous study has reported an association between DTR and daily emergency room (ER) visits for URI.

The present study aimed to evaluate the short-term effect of DTR on ER visits for URI in Seoul, Korea, between 2009 and 2013. We sought to examine the difference in the effect of DTR between groups by stratification analysis by gender and age.

\section{Materials and methods Study area}

Seoul $\left(37^{\circ} 25^{\prime}-37^{\circ} 41^{\prime} \mathrm{N}, 126^{\circ} 45^{\prime}-127^{\circ} 11^{\prime} \mathrm{E}\right)$ is located in the northwest of the Korean peninsula and is approximately halved into northern and southern regions by the Han River. In 2011, it had an area of $605.21 \mathrm{~km}^{2}$ and has a gross east-west distance of $36.78 \mathrm{~km}$ and $30.30 \mathrm{~km}$ south-north. In the same year, the city's total population was $10,528,774$, of which $9.97 \%$ was $\geq 65$ and $4.06 \%$ were $\leq 5$ years of age [15]. The climate is intermediate between continental and oceanic. In the winter, a seasonal wind from the northwest results in dry and low temperatures, while in the summer, it is usually very hot and humid resulting from the effects of subtropical oceanic air currents.

\section{Study population}

Data regarding daily emergency room (ER) visits for acute upper respiratory tract infections (URI) between January 1, 2009, and December 31, 2013 were collected from the National Emergency Department Information System (NEDIS). The NEDIS is a real-time reporting system for ER visits in Korea. The coverage rate for all hospitals in Seoul was 58\% in 2009, 58\% in 2010, $59 \%$ in $2011,60 \%$ in 2012 , and $81 \%$ in 2013 [16].

URI cases were defined as patients assigned discharge diagnostic codes J00 to J06 from the International Classification of Diseases, 10th Revision (ICD-10). ER visits for URI were defined as the number of ER visits for URI divided by the mid-year population per 1000 for each year.

The dataset contained no personally identifiable patient information. Dependent variables in the analysis included date of visit and patient age and sex. This study analyzed publicly available data sets and was, therefore, exempt from institutional review board approval and requirements for informed consent.

\section{Environmental data}

Daily mean climate was calculated for average temperature $\left({ }^{\circ} \mathrm{C}\right)$, DTR $\left({ }^{\circ} \mathrm{C}\right)$, and relative humidity (\%), in Seoul between December 1, 2008, and December 31, 2013. Local climate data were obtained from the Korea Climate Administration and were measured at a fixed-site station ( $37^{\circ} 34^{\prime} \mathrm{N}, 126^{\circ} 57^{\prime}$ E [elevation, $85.8 \mathrm{~m}$ ]) [17].

Estimates of daily mean ambient concentrations of air pollution were obtained from the National Ambient Air Quality Monitoring Information System maintained by the Ministry of Environment, which collects data on air pollution levels through automated fixed-site monitoring stations [18]. Air pollutant data were obtained from 25 observation stations in Seoul between December 1, 2008, and December 31, 2013. Independent variables included in the analysis were particulate matter of median aerometric diameter $<10$ microns $\left(\mathrm{PM}_{10}\left[\mu \mathrm{g} / \mathrm{m}^{3}\right]\right)$ and ozone $\left(\mathrm{O}_{3}\right.$ [in parts per billion (ppb)]) measured at each station.

\section{Statistical analysis}

From 2009 to 2013, the distribution of daily ER visits for URI and environmental data are presented in a timeseries plot. We explored the descriptive statistics of daily URI cases, climate, and air pollutant variables and performed Spearman's correlation analysis between URI cases and the exposure variables. The lag structures consisted of the event day and the seven previous days. We used the semi-parametric generalized additive model (GAM) approach with log link to explore the associations between daily DTR and ER visits for URI [19].

The basic model is as follows:

$$
\begin{aligned}
\log [\mathrm{E}(\mathrm{Yt})]= & \alpha+\mathrm{s}(\mathrm{DTR})+\mathrm{s}(\text { average temperature }) \\
& +\mathrm{s}(\text { relative humidity })+\mathrm{s}(\text { PM10 }) \\
& +\mathrm{s}(\mathrm{O} 3)+\text { time }+\mathrm{DOW}+\text { Holiday } \\
& +\sin \frac{2 \pi t}{T}+\cos \frac{2 \pi t}{T}
\end{aligned}
$$

in which $t$ refers to the day of the observation; $\mathrm{E}(\mathrm{Yt})$ denotes the estimated daily ER visits for URI on day $t ; \alpha$ is the intercept; $\mathbf{s}()$ denotes a thin plate regression spline function for nonlinear variables; time is days of calendar time on day $t$; $T$ is the length of seasonal cycle, 365 days; DOW is the day of the week; and Holiday denotes public holidays.

Potential confounders, such as long-term trend of time and seasonality, were controlled for using time term and Fourier terms, respectively [20]. Climate factors and air pollutants variables were controlled for using thin plate regression splines as a smoothing function of the GAM. DOW and Holiday were adjusted as dummy variables in 
the model. We used the negative binomial model because of overdispersion of the data [21].

Stratified analyses were performed to examine whether associations between DTR and ER visits for URI were similar across age and sex. Residuals of the basic models were used to check whether there were discernible patterns and autocorrelation by means of residual plots.

The best model is the one with the smallest Akaike information criterion (AIC) value. All statistical analyses and plot constructions were performed using the $m g c v$ package and $g a m R R$ package of the $\mathrm{R}$ software version 3.6.1 ( $\mathrm{R}$ foundation for Statistical Computing, Vienna, Austria).

\section{Results}

There were 529,527 ER visits for URI between 2009 and 2013 (Table 1); the mean number of ER visits for URI per day during the same period was 290.02

Table 1 Daily emergency room visits for acute upper respiratory tract infections according to several characteristics in Seoul, Korea, 2009 to 2013 ( $n=529,527)$

\begin{tabular}{|c|c|c|}
\hline Characteristic & Cases, $n$ & $\%$ \\
\hline \multicolumn{3}{|l|}{ Sex } \\
\hline Male & 278,777 & 52.7 \\
\hline Female & 250,750 & 47.3 \\
\hline \multicolumn{3}{|l|}{ Age, years } \\
\hline $0-5$ & 297,364 & 56.2 \\
\hline $6-18$ & 74,337 & 14.0 \\
\hline $19-64$ & 147,451 & 27.8 \\
\hline$\geq 65$ & 10,375 & 2.0 \\
\hline \multicolumn{3}{|l|}{ Year } \\
\hline 2009 & 119,137 & 22.5 \\
\hline 2010 & 119,104 & 22.5 \\
\hline 2011 & 92,388 & 17.4 \\
\hline 2012 & 104,295 & 19.7 \\
\hline 2013 & 94,603 & 17.9 \\
\hline \multicolumn{3}{|l|}{ Day of the week } \\
\hline Monday & 65,777 & 12.4 \\
\hline Tuesday & 58,966 & 11.1 \\
\hline Wednesday & 57,394 & 10.9 \\
\hline Thursday & 57,818 & 10.9 \\
\hline Friday & 57,770 & 10.9 \\
\hline Saturday & 84,552 & 16.0 \\
\hline Sunday & 147,250 & 27.8 \\
\hline \multicolumn{3}{|l|}{ Public holidays } \\
\hline Holiday & 262,001 & 49.5 \\
\hline Non-holiday & 267,526 & 50.5 \\
\hline
\end{tabular}

(range, 74-1,942 visits) (Table 2). The number of ER visits for URI was the highest in $2009(0.032 \pm 0.026$ per 1000 persons $)$ and $2010(0.032 \pm 0.018$ per 1000 persons) and the lowest in $2011(0.025 \pm 0.015$ per 1000 persons).

In particular, a remarkably high rate of URI was observed among the $0-5$-year age group (56.2\%). The proportion of URI cases on public holidays (49.5\%), including Saturday and Sunday, was similar to that on non-holidays (50.5\%). Public holidays were 110 days in 2009, 113 days in 2010, and 116 days from 2011 to 2013, respectively. Furthermore, the total number of URI cases on Sunday (27.8\%) was highest compared with any other day of week, followed by Saturday (16\%).

During the study period, the mean of DTR from 2009 to 2013 was $8.05{ }^{\circ} \mathrm{C}$ (range, $1.10-17.6{ }^{\circ} \mathrm{C}$ ) (Table 2). The daily average temperature was $12.41{ }^{\circ} \mathrm{C}$ (range, $-14.5-31.8{ }^{\circ} \mathrm{C}$ ); additionally, relative humidity (RH) was $60.1 \%$ (range, 20-97\%). The mean concentrations of $\mathrm{PM}_{10}$ and $\mathrm{O}_{3}$ were $47.14 \mu \mathrm{g} / \mathrm{m}^{3}$ and $20.6 \mathrm{ppb}$, respectively.

The number of daily ER visits for URI, DTR $\left({ }^{\circ} \mathrm{C}\right)$, average temperature $\left({ }^{\circ} \mathrm{C}\right), \mathrm{RH}(\%), \mathrm{PM}_{10}(\mu \mathrm{g} / \mathrm{m} 3)$, and $\mathrm{O}_{3}$ (ppb) during the study period are presented in Fig. 1. ER visits for URI varied seasonally, with a major peak in the winter months (December to February) and a minor peak in the spring (March to May).

The smoothed exposure-response plots of DTR and ER visits for URI at the smallest AIC after controlling for average temperature, $\mathrm{RH}, \mathrm{PM}_{10}, \mathrm{O}_{3}$, time trend, seasonality, DOW, and holiday are presented in Fig. 2. The plots demonstrate a clear nonlinear relationship, except under 5 years old. Overall, as DTR increased, the incidence of URI increased.

Table 3 shows the results of analyzing the piecewise regression model by finding the breakpoint value based on the results of the multivariate analysis. When the DTR (lag 02) was $6.57{ }^{\circ} \mathrm{C}$ to $11.03{ }^{\circ} \mathrm{C}$, the percent change was significant at $6.01 \%$ (95\% CI 2.45-9.69) for every $1{ }^{\circ} \mathrm{C}$ increase in youth subjects aged for 6 to 18 years.

\section{Discussion}

The results of our study demonstrated the short-term effect of DTR on ER visits for acute URI in Korea. After adjustment for potential confounding by time-trends, seasonality, DOW, public holidays, average temperature, $\mathrm{RH}, \mathrm{PM}_{10}$, and $\mathrm{O}_{3}$, we found that the incidence of URI increased with higher DTR. Evidence accumulated in this study suggests that DTR was an important risk factor for URI.

In the multi-variable model that controlled for climate factors and air pollutants, the percentage change in ER 
Table 2 Summary statistics of daily emergency room visits for acute upper respiratory tract infections, and climate factors and air pollutants in Seoul, Korea, 2009 to 2013

\begin{tabular}{|c|c|c|c|c|c|c|c|}
\hline Daily data & Mean & SD & Min & P25 & P50 & P75 & Max \\
\hline Upper respiratory tract infections & 290.02 & 193.29 & 74 & 174 & 227 & 331.5 & 1942 \\
\hline \multicolumn{8}{|l|}{ Climate factors } \\
\hline Diurnal temperature range $\left({ }^{\circ} \mathrm{C}\right)$ & 8.05 & 2.75 & 1.10 & 6.10 & 8.10 & 10 & 17.6 \\
\hline Average temperature $\left({ }^{\circ} \mathrm{C}\right)$ & 12.41 & 11.03 & -14.5 & 3.3 & 13.9 & 22.7 & 31.8 \\
\hline Relative humidity (\%) & 60.14 & 15.12 & 20 & 49 & 60 & 71 & 97 \\
\hline \multicolumn{8}{|l|}{ Air pollutants } \\
\hline $\mathrm{PM}_{10}\left(\mu \mathrm{g} / \mathrm{m}^{3}\right)$ & 47.14 & 28.74 & 4.96 & 28.59 & 41.83 & 57.46 & 298 \\
\hline Ozone (parts per billion) & 20.6 & 11.1 & 1.8 & 11.7 & 19.3 & 28.0 & 71.1 \\
\hline
\end{tabular}

$S D$ standard deviation, Min minimum, $P$ percentile, Max maximum, $P M_{10}$ particulate matter with a median aerometric diameter $<10$ microns

visits for URI and their associations with DTR are summarized in Table S2. DTR was associated with ER visits for URI for all patients on lag 02 days. The cumulative day (lag 02) effect of DTR per $1{ }^{\circ} \mathrm{C}$ increment was associated with a $1.18 \%(95 \%$ CI $0.27-2.09)$ increase in total URI. In Cordoba, Argentina, hospital admissions for URI increased by $0.29 \%$ (95\% CI $0.08-0.67 \%)$ at lag 0 [10]. In Seoul, Korea, hospital admissions for total respiratory disease increase by $1.3 \%$ ( $95 \%$ CI $0.3-2.4 \%$ ) at lag 09 [11]. In Shanghai, China, ER visits for respiratory tract infections increased by $2.08 \%$ (95\% CI $1.24-2.93 \%)$ at lag 01 [9].

In subgroup analyses for sex, the effect of DTR variation on the URI was similar for both female and male. The female group increased by $1.32 \%$ (95\% CI $0.35-2.30 \%)$ at lag 02 , and the male group increased by $1.05 \%$ (95\% CI $0.16-1.95 \%)$ at lag 02 . Otherwise, in Beijing, China, the ER admissions for total respiratory disease among males increased by $1.17 \%$ (95\% CI $0.27-3.18 \%$ ) at lag 07 , but the female group did not exhibit a DTR effect [8].

In age-specific analysis, we found that children $(\leq 5$ years) were affected by DTR per $1{ }^{\circ} \mathrm{C}$, with cumulative effect estimates (lag 02) of 0.90\% (95\% CI, 0.15-1.65\%), adults (19-64 years) with $2.98 \%$ (95\% CI $1.32-4.67 \%)$ at lag 07 , and the elderly ( $\geq 65$ years of age) with $3.63 \%$ (95\% CI 1.08-6.25\%) at lag 07; however, youth (6-18 years) were not affected (Figure S1). In Cordoba, Argentina, hospital admissions for URI increased in children ( $\leq 5$ years of age) with a $0.52 \%$ ( $95 \%$ CI, $0.12-$ $0.93 \%)$ and the elderly ( $\geq 60$ years) with $1.14 \%$ (95\% CI $0.41-1.93 \%)$ at lag 0 . However, youth (6-18 years) and adults (19-59 years) were not significantly affected [10]. As illustrated in Figure S2, in the youth (6-18 years) group, there are certain temperature intervals with significant relative risk. When the DTR of lag 02 was 9.47 ${ }^{\circ} \mathrm{C}$, the relative risk was 1.277 (95\% limit 1.264-1.289). It can be seen that the low DTR distribution at lag 02 mainly occurs in the summer and winter, and the high DTR mainly occurs in the spring and autumn. In Fig. 2, the effect of DTR decreased and not significant when the DTR more than $10{ }^{\circ} \mathrm{C}$. This is probably because the single day exceeds $10{ }^{\circ} \mathrm{C}$ are rare, and the cumulative day exceed $10{ }^{\circ} \mathrm{C}$ is more rare. Table $\mathrm{S} 2$ shows that the effects of cumulative day DTR are greater than the effects of any single day's DTR. In age less than 5 , the cumulative day 03 has the greatest effect on URI, while in the age over 19, the greater the cumulative day within a week, the greater the effect on the incidence of URI. It can be assumed that having different incubation periods of the pathogens can be a factor in explaining this lag effect of cumulative day DTR. The different distribution of causative pathogens by age may also explain the difference of lag by age. Another plausible explanation for the lag effect by age is the transmission characteristics of respiratory pathogen. Some respiratory viruses like influenza, make outbreaks in children, and then transmitted to adults [22]. However, the evidence to explain this lag effects should be explored in further studies.

Based on the results of the piecewise regression model (Table 3), the percent change of 6-18 years of age compared to other ages is presumed to be influenced by the group life that occurs at the beginning of the semester in spring and autumn. In this regard, DTR was associated with an ER visits for URI in all age groups.

The effect of DTR is also associated with respiratory syncytial virus (RSV), asthma, and chronic obstructive pulmonary disease (COPD). In Fukuoka, Japan, the number of RSV cases from 2006 to 2012 increased, with an RR of $3.30 \%$ (95\% CI $1.62-6.60 \%$ ) for a $1{ }^{\circ} \mathrm{C}$ increase at lag 0-16 weeks [23]. In Brisbane, Australia, ER admissions for asthma among the children (0-14 years of age) from 2003 to 2009, increased by 31\% (95\% CI 11-58\%) of $15{ }^{\circ} \mathrm{C}$ versus $10{ }^{\circ} \mathrm{C}$, at a moving average lag of 09 [24]. 

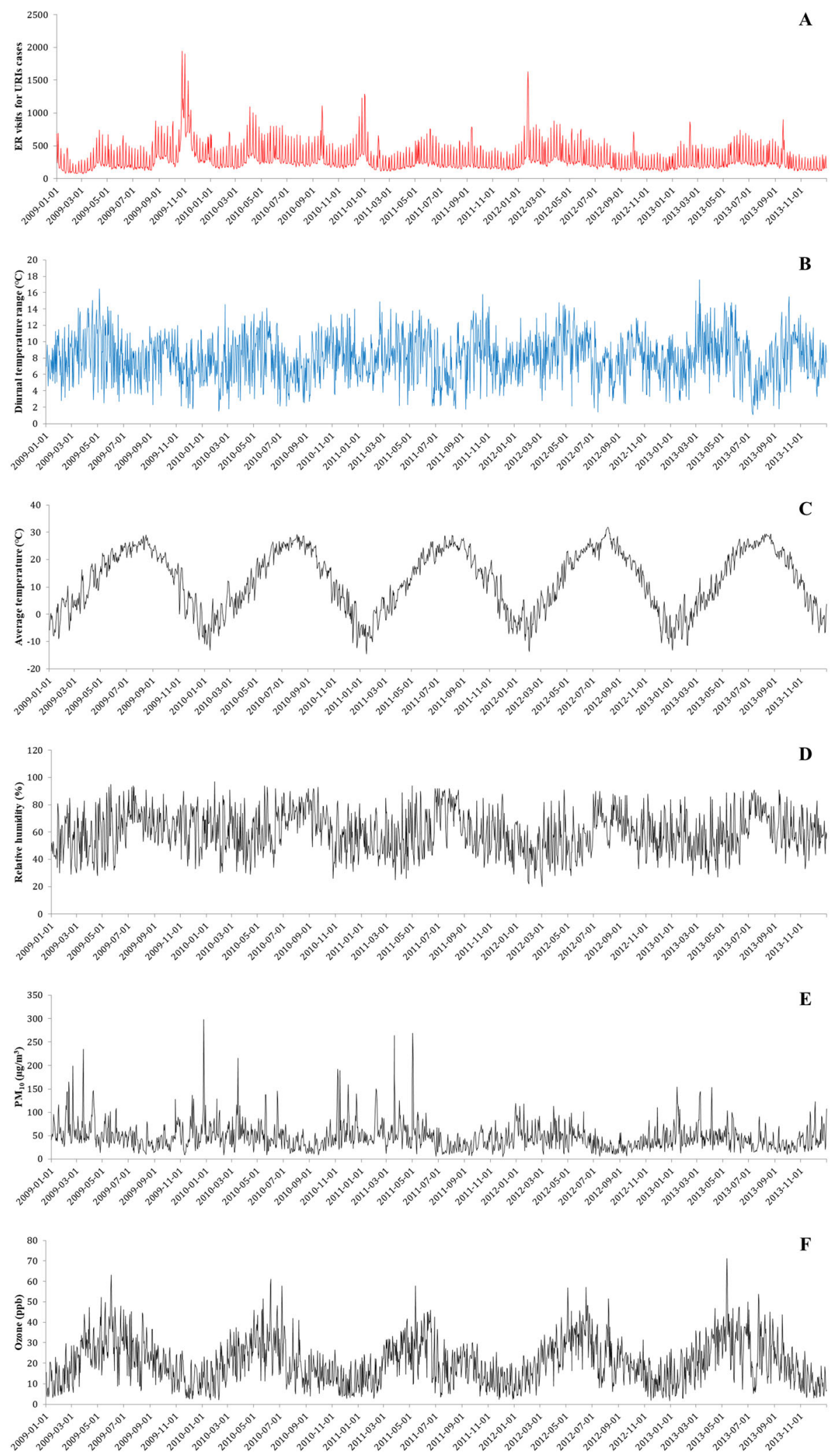

Fig. 1 Time series plot of (a) emergency room (ER) visits for upper respiratory tract infections (URI) (number of daily cases), (b) diurnal temperature range (DTR), (c) average temperature, (d) relative humidity, (e) particulate matter with a median aerometric diameter $<10$ microns $\left(\mathrm{PM}_{10}\right)$, and (f) ozone $\left(\mathrm{O}_{3}\right)$ in Seoul, Korea, 2009 to 2013 

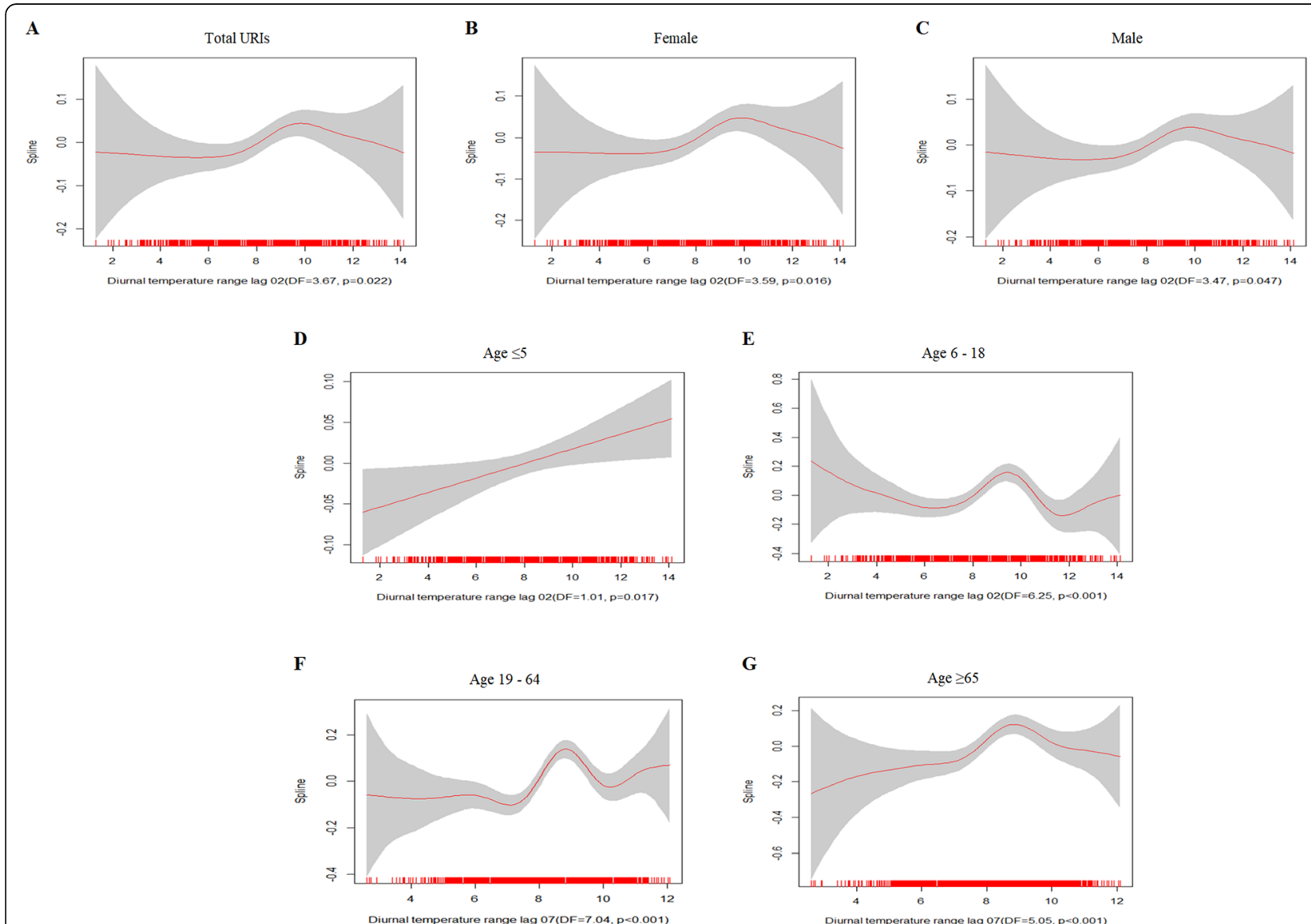

Fig. 2 The smoothed exposure-response curves between diurnal temperature range (DTR) and emergency room (ER) visits for upper respiratory tract infections (URI) in different subgroups in Seoul, Korea, 2009 to 2013. The line represents a spline curve and the shaded area represents the $95 \%$ confidence intervals. The models were controlled for the average temperature, relative humidity, particulate matter with a median aerometric diameter $<10$ microns $\left(\mathrm{PM}_{10}\right)$, ozone $\left(\mathrm{O}_{3}\right)$, time trend, seasonality, day of the week (DOW), and holiday

ER admissions for COPD between 2001 and 2002 in Taichung, Taiwan, increased by $13.9 \%$ (95\% CI $0.8-28.8 \%$ ) of $\geq 9.6{ }^{\circ} \mathrm{C}$ versus $<6.6{ }^{\circ} \mathrm{C}[25]$. Also, the DTR was associated with stroke, COPD, and coronary arteryrelated death [26], and the morbidity of childhood pneumonia [27].

Results of the present study support a relationship between DTR and ER visits for URI. While the exact physiological mechanism(s) of effect of DTR on URI is no clear, previous study found that sudden temperature changes can cause inflammatory responses in nasal epithelial cells [28], which could lead to URI.

There were several limitations to the present study. First, data regarding ER visits for URI were from only one city, which may have introduced selection bias. In addition, although there was an increase in coverage for all hospitals in Seoul, there was no tendency to increase the number of cases by year. ER visits show a severe level, and small proportion of the total effects of DTR. And, because our raw data uses public data that cannot identify individuals, we could not identify re-visits for patients with URI from the available data. Second, we used outdoor monitoring data to represent personal exposure to DTR and other climate factors and air pollutants, which may have resulted in exposure misclassification(s). However, exposure measurement error was unavoidable, but has been shown to bias toward the null. It makes the association underestimated [29]. Third, some previous studies have found that particulate matter $<2.5 \mu \mathrm{m}$ in aerodynamic diameter $\left(\mathrm{PM}_{2.5}\right)$ is an adverse factor for URI $[30,31]$. However, data regarding $\mathrm{PM}_{2.5}$ were unavailable during the study period; therefore, further studies need are warranted. And we could not consider seasonal allergies as a modifier due to lack of information. And further studies related to the weather app notices need to be conducted to prevent not 
Table 3 The effect of a $1{ }^{\circ} \mathrm{C}$ increase in diurnal temperature range on daily emergency room visits for acute upper respiratory tract infections (URI) in Seoul, Korea, 2009 to 2013

\begin{tabular}{|c|c|c|c|c|c|c|}
\hline & Lag & Break point $\left({ }^{\circ} \mathrm{C}\right)$ & Percent change & $95 \% \mathrm{C}$ & & $p$ value \\
\hline \multirow[t]{2}{*}{ Total URI } & 02 & $<6.57$ & 0.84 & -2.79 & 4.61 & 0.6481 \\
\hline & & $\geq 6.57$ & 1.42 & 0.04 & 2.82 & 0.0401 \\
\hline \multirow[t]{2}{*}{ Female } & 02 & $<6.57$ & 0.56 & -3.31 & 4.59 & 0.7746 \\
\hline & & $\geq 6.57$ & 1.54 & 0.07 & 3.03 & 0.0364 \\
\hline \multirow[t]{2}{*}{ Male } & 02 & $<6.57$ & 1.05 & -2.50 & 4.74 & 0.5583 \\
\hline & & $\geq 6.57$ & 1.31 & -0.05 & 2.69 & 0.0547 \\
\hline \multirow[t]{2}{*}{ Age $\leq 5$ years } & 02 & $<6.57$ & 1.01 & -2.07 & 4.18 & 0.5171 \\
\hline & & $\geq 6.57$ & 1.45 & 0.32 & 2.60 & 0.0103 \\
\hline \multirow[t]{3}{*}{ Age $6-18$ years } & 02 & $<6.57$ & -2.32 & -8.19 & 3.93 & 0.45 \\
\hline & & $6.57 \leq \mathrm{BP}<11.03$ & 6.01 & 2.45 & 9.69 & 0.0006 \\
\hline & & $\geq 11.03$ & 8.55 & -0.50 & 18.42 & 0.0593 \\
\hline \multirow[t]{2}{*}{ Age 19-64 years } & 07 & $<6.73$ & -2.13 & -7.79 & 3.88 & 0.47 \\
\hline & & $\geq 6.73$ & 2.77 & 0.39 & 5.20 & 0.0195 \\
\hline \multirow[t]{2}{*}{ Age $\geq 65$ years } & 07 & $<6.73$ & 2.48 & -7.59 & 13.65 & 0.6357 \\
\hline & & $\geq 6.73$ & 1.66 & -1.83 & 5.28 & 0.3449 \\
\hline
\end{tabular}

Bolded values indicate statistically significant differences (i.e., $p<0.05$ )

only URI, which are affected by the DTR but also various health outcomes.

\section{Conclusions}

In summary, our study found that DTR was associated with ER visits for URI in Seoul between 2009 and 2013. In addition, the results suggested that age is a modifier of the incidence of URI according to DTR.

\section{Supplementary Information}

The online version contains supplementary material available at https://doi. org/10.1186/s12199-021-00974-w.

Additional file 1: Table S1. Spearman's correlations among emergency room visits for upper respiratory tract infections, climate factors, and air pollutants in Seoul, Korea, 2009 to 2013.

Additional file 2: Table S2. Percent change in emergency room visits for acute upper respiratory tract infections (URI) associated with a $1^{\circ} \mathrm{C}$ increase in dirunal temperature range in Seoul, Korea, 2009 to 2013.

Additional file 3: Figure S1. Percentage change (\%) in emergency room (ER) visits for upper respiratory tract infections (URI) in different subgroups associated with a $1^{\circ} \mathrm{C}$ increase in diurnal temperature range (DTR) in Seoul, Korea, 2009-2013. The X-axis shows the lag of DTR $\left({ }^{\circ} \mathrm{C}\right)$ in the different subgroups. The Y-axis is the estimated percentage change (\%). The circles represent the central estimate and the vertical lines the 95\% confidence interval. The models were controlled for the average temperature, relative humidity, particulate matter with a median aerometric diameter $<10$ microns $\left(\mathrm{PM}_{10}\right)$, ozone $\left(\mathrm{O}_{3}\right)$, time trend, seasonality, day of the week (DOW), and holidays.

Additional file 4: Figure S2. The relative risk (RR) between diurnal temperature range (DTR) and emergency room (ER) visits for upper respiratory tract infections (URI) in different subgroups in Seoul, Korea, 2009-2013. The $\mathrm{X}$-axis shows the moving averages of DTR $\left({ }^{\circ} \mathrm{C}\right)$. The $\mathrm{Y}$-axis represents the estimated relative risk (RR). The line represents central estimates and the dotted lines represent the 95\% upper and lower limits. The models were controlled for the average temperature, relative humidity, particulate matter with a median aerometric diameter $<10$ microns $\left(P M_{10}\right)$, ozone $\left(\mathrm{O}_{3}\right)$, time trends, seasonality, day of the week (DOW), and holidays.

\section{Acknowledgements}

No applicable.

\section{Authors' contributions}

BCC contributed to the concept and design of the study. JYJ contributed to the literature search, data management, data analysis, and drafting. BCC contributed to the development the analytical plan, interpretation of the results, and critically reviewed the draft. All authors revised the manuscript. The authors read and approved the final manuscript.

\section{Funding}

This study was supported by a grant from the Transgovernmental Enterprise for Pandemic Influenza in Korea (TEPIK), which is a part of the Korea Healthcare Technology R\&D Project by the Ministry of Health and Welfare, Republic of Korea (grant no.: A103001)

\section{Availability of data and materials}

The data were obtained from the National Emergency Department Information System (NEDIS) of National Emergency Medical Center in Korea. Due to legal restrictions, the database cannot be made publicly available. However, data are available from the authors upon reasonable request and with permission of the National Emergency Medical Center.

\section{Declarations}

\section{Ethics approval and consent to participate}

This study was approved by the Institutional Review Board of the Korea University (IRB: KUIRB-17-EX-257-A-1). Informed consent was waived because the data were de-identified before the analysis. 


\section{Consent for publication}

Not applicable.

\section{Competing interests}

The authors declare that they have no competing interests.

Received: 26 December 2020 Accepted: 18 April 2021

Published online: 03 May 2021

\section{References}

1. Monto AS. Epidemiology of viral respiratory infections. Am J Med. 2002; $112(6 \mathrm{~A}): 4 \mathrm{~S}-12 \mathrm{~S}$.

2. Grief SN. Upper respiratory infections. Prim Care. 2013;40(3):757-70. https:// doi.org/10.1016/j.pop.2013.06.004

3. Heikkinen T, Järvinen A. The common cold. Lancet. 2003:361(9351):51-9. https://doi.org/10.1016/S0140-6736(03)12162-9.

4. Zoorob R, Sidani MA, Fremont RD, Kihlberg C. Antibiotic use in acute upper respiratory tract infections. Am Fam Physician. 2012;86:817-22.

5. Eccles R. An explanation for the seasonality of acute upper respiratory tract viral infections. Acta Otolaryngol. 2002;112:183-91.

6. Mäkinen TM, Juvonen R, Jokelainen J, Harju TH, Peitso A, Bloigu A, et al. Cold temperature and low humidity are associated with increased occurrence of respiratory tract infections. Respir Med. 2009;103(3):456-62. https://doi.org/10.1016/j.rmed.2008.09.011.

7. Hajat S, Haines A. Associations of cold temperatures with GP consultations for respiratory and cardiovascular disease amongst the elderly in London. Int J Epidemiol. 2002;31(4):825-30. https://doi.org/10.1093/ije/31.4.825.

8. Wang MZ, Zheng S, He SL, et al. The association between diurnal temperature range and emergency room admissions for cardiovascular, respiratory, digestive and genitourinary disease among the elderly: A time series study. Sci Total Environ. 2013;456-457:370-5.

9. Ge WZ, Xu F, Zhao ZH, Zhao JZ, Kan HD. Association between diurnal temperature range and respiratory tract infections. Biomed Environ Sci. 2013;26:222-5.

10. Carreras $H$, Zanobetti A, Koutrakis P. Effect of daily temperature range on respiratory health in Argentina and its modification by impaired socioeconomic conditions and $\mathrm{PM}_{10}$ exposures. Environ Pollut. 2015;206:175-82. https://doi.org/10.1016/j.envpol.2015.06.037.

11. Lim $\mathrm{YH}$, Hong $\mathrm{YC}$, Kim H. Effects of diurnal temperature range on cardiovascular and respiratory hospital admissions in Korea. Sci Total Environ. 2012:417-418:55-60.

12. Lee $\mathrm{HJ}$, Jin $\mathrm{MH}$, Lee $\mathrm{JH}$. The association of weather on pediatric emergency department visits in Changwon, Korea (2005-2014). Sci Total Environ. 2016; 551:699-705.

13. Lee SW, Yon DK, James CC, Lee S, Koh HY, Sheen YH, et al. Short-term effects of multiple outdoor environmental factors on risk of asthma exacerbations: age-stratified time-series analysis. J Allergy Clin Immunol. 2019;144(6):1542-50. https://doi.org/10.1016/j.jaci.2019.08.037.

14. Zhang Y, Yu C, Yang J, Zhang L, Cui F. Diurnal temperature range in relation to daily mortality and years of life lost in Wuhan, China. Int J Environ Res Public Health. 2017;14(8):891. https://doi.org/10.3390/ijerph14080891.

15. Seoul Metropolitan Government. Seoul statistical yearbook. 2012. Available online: http://data.seoul.go.kr/together/statbook/statbookList.do. Accessed 6 Dec 2020.

16. National Emergency Medical Center. Yearbook of Emergency Medical Statistics. Available online: http://www.e-gen.or.kr/nemc/statistics_annual_ report.do. Accessed 6 Dec 2020.

17. Korea Climate Administration. Annual Climatological Report. 2011. Available at: https://data.kma.go.kr/cmmn/main.do. Accessed 6 Dec 2020.

18. Ministry of Environment. National Ambient air quality Monitoring Information System. Available at: https://www.airkorea.or.kr/index. Accessed 6 Dec 2020

19. Guisan A, Edwards TC, Hastie T. Generalized linear and generalized additive models in studies of species distributions: setting the scene. Ecol Model. 2002;157(2-3):89-100. https://doi.org/10.1016/S0304-3800(02)00204-1.

20. Stolwijk AM, Straatman H, Zielhuis GA. Studying seasonality by using sine and cosine functions in regression analysis. J Epidemiol Community Health. 1999:53(4):235-8. https://doi.org/10.1136/jech.53.4.235.

21. Lindén A, Mäntyniemi S. Using the negative binomial distribution to model overdispersion in ecological count data. Ecology. 2011;92(7):1414-21. https://doi.org/10.1890/10-1831.1.
22. Longini IM Jr, Koopman JS, Monto AS, Fox JP. Estimating household and community transmission parameters for influenza. Am J Epidemiol. 1982; 115(5):736-51. https://doi.org/10.1093/oxfordjournals.aje.a113356.

23. Onozuka D. The influence of diurnal temperature range on the incidence of respiratory syncytial virus in Japan. Epidemol Infect. 2015;143(4):813-20. https://doi.org/10.1017/S0950268814001575.

24. Xu Z, Huang C, Su H, Turner LR, Qiao Z, Tong S. Diurnal temperature range and childhood asthma: a time-series study. Environ Health. 2013;12(1):12. https://doi.org/10.1186/1476-069X-12-12.

25. Liang WM, Liu WP, Kuo HW. Diurnal temperature range and emergency room admissions for chronic obstructive pulmonary disease in Taiwan. Int J Biometeorol. 2009;53(1):17-23. https://doi.org/10.1007/s00484-008-0187-y.

26. Cheng J, Xu Z, Zhu R, Wang $X$, Jin L, Song J, et al. Impact of diurnal temperature range on human health: a systematic review. Int J Biometeorol. 2014;58(9):2011-24. https://doi.org/10.1007/s00484-014-0797-5.

27. Zeng J, Lu C, Deng Q. Prenatal exposure to diurnal temperature variation and early childhood pneumonia. J Therm Biol. 2017;65:105-12. https://doi. org/10.1016/j.jtherbio.2017.02.012

28. Graudenz GS, Landgraf RG, Jancar $S$, et al. The role of allergic rhinitis in nasal responses to sudden temperature changes. J Allergy Clin Immunol. 2006;118(5):1126-32. https://doi.org/10.1016/j.jaci.2006.07.005.

29. Armstrong BG. Effect of measurement error on epidemiological studies of environmental and occupational exposures. Occup Environ Med. 1998; 55(10):651-6. https://doi.org/10.1136/oem.55.10.651.

30. Darrow LA, Klein M, Flanders WD, Mulholland JA, Tolbert PE, Strickland MJ. Air pollution and acute respiratory infections among children 0-4 years of age: an 18-year time-series study. Am J Epidemiol. 2014;180(10):968-77. https://doi.org/10.1093/aje/kwu234.

31. Xu Q, Li X, Wang S, Wang C, Huang F, Gao Q, et al. Fine particulate air pollution and hospital emergency room visits for respiratory disease in urban areas in Beijing, China, in 2013. PLoS One. 2016;11(4):e0153099. https://doi.org/10.1371/journal.pone.0153099.

\section{Publisher's Note}

Springer Nature remains neutral with regard to jurisdictional claims in published maps and institutional affiliations.

Ready to submit your research? Choose BMC and benefit from:

- fast, convenient online submission

- thorough peer review by experienced researchers in your field

- rapid publication on acceptance

- support for research data, including large and complex data types

- gold Open Access which fosters wider collaboration and increased citations

- maximum visibility for your research: over $100 \mathrm{M}$ website views per year

At $\mathrm{BMC}$, research is always in progress.

Learn more biomedcentral.com/submissions 